\title{
DECAY RESISTANCE OF FOUR FAST-GROWING EUCALYPTS WOOD EXPOSED TO THREE TYPES OF FIELDS
}

\author{
Rafael de Avila Delucis ${ }^{1, \star}$, Pedro Henrique Gonzales de Cademartori², \\ André Luiz Missio ${ }^{3}$, Darci Alberto Gatto ${ }^{1}$
}

\begin{abstract}
The evaluation of wood durability enables the definition of reliable parameters to predict the servicelife of wood-based products. This study aimed to evaluate the wood deterioration of four fast-growing eucalypts species (Eucalyptus botryoides, Corymbia citriodora, Eucalyptus paniculata e Eucalyptus tereticornis) exposed to three field tests (outdoor, flooded site and forest canopy) during 540 days. The physical properties measured were: mass loss, density and moisture content. Furthermore, we determined changes in wood color by CIEL*a*b* method and performed a visual analysis by CEN grades. Among the four wood eucalypts, Eucalyptus tereticornis presented the highest decay resistance. The flooded site presented the best conditions for the proliferation of xylophagous agents. Mature wood was least susceptible to deterioration than juvenile wood.
\end{abstract}

Keywords: Biodegradation, biodeterioration, Corymbia, density, Eucalyptus, lightness.

\section{INTRODUCTION}

Currently, the use of wood and wood-based products is conditioned to their financial cost. Therefore, knowledge of wood durability is important because it enables planning for the service-life of the wood products. (Boasiako and Allotey 2010).

Brischke and Rolf-Kiel 2010, affirmed that field tests are a good alternative to determine the decay resistance of wood, since this method subjects the wood samples to real conditions when in service. According to Little et al. (2013), the field tests enable the investigation of both fungi and termite degradation at the same time.

Many factors influence the degree of degradation of wood in contact with soil, for instance, chemical composition (Latorraca et al. 2011), moisture content of wood (Thybring 2013), soil characteristics: $\mathrm{pH}$, salinity, organic matter and nutrient content (Brischke et al. 2014), climatic conditions: relative humidity and temperature (Raberg et al. 2005). Thus, microbial activity in field tests vary between and within the exposure sites (Brischke et al. 2014).

\footnotetext{
${ }^{1}$ College of Materials Engineering (PPGCEM), Development Centre of Technology (CDTec), Federal University of Pelotas, Pelotas, RS, Brazil darcigatto@yahoo.com

${ }^{2}$ Wood and Forestry Science Centre (PPGEF), Federal University of Paraná, Curitiba, PR, Brazil. pedrocademartori@gmail.com ${ }^{3}$ Forestry Engineering (PPGEF), Forest Products Laboratory, Centre of Rural Sciences, Federal University of Santa Maria, Santa Maria, Brazil. missio08@gmail.com

"Corresponding author: r.delucis@hotmail.com

Received: 21.10.2014 Accepted: 02.10.2015
} 
Wood from Eucalyptus genus is a good example of that variability, since species of the same genus can present different degrees of decay resistance. According to AS 5604 of the Australian Standard 2003, the durability of Eucalyptus paniculata and Eucalyptus tereticornis woods in contact with soil is greater than 25 years. On the other hand, Eucalyptus botryoides wood presents a reliable natural durability between 5 and 15 years. Corymbia citriodora, even if it is not a species of Eucalyptus genus, is commonly known as an eucalypt. Australian Standard reports that durability of Corymbia citriodora wood is between 5 and 15 years.

Magalhães et al. (2012), pointed out that evaluation of the durability of wood from Brazil is influenced by the fast-growth of the trees. Higher growth ratings increase the proportion of sapwood, which is more susceptible to degradation than heartwood. Thus, wood from species such as Corymbia citriodora, which is commonly known for its higher durability, will only present suitable properties for use in service with the application of preservative products.

Venmalar et al. (2011), affirmed that the durability of wood from fast-growing species is not evaluated in tropical countries like Brazil, as well as Asia, Europe and Oceania. For that, nondestructive tests (NDT) have been widely used (Raberg et al. 2005, Venalainen et al. 2014).

Visual analysis as a function of phytosanitary conditions of the materials is one of the most common techniques applied by the scientific community. Nevertheless, this technique is subjective and the result can be unreliable. Thus, other quantitative data should be used to support this analysis (Raberg et al. 2005).

Mass loss is the main parameter to characterize wood exposed to field tests (Curling et al. 2002, Raberg et al. 2005). Nevertheless, Venalainen et al. (2014), criticize the use of traditional methods used by other researchers to analyze wood, since practical parameters such as hardness and aesthetic characteristics are not considered as important as the mass loss.

We monitored the deterioration of both juvenile and mature wood of four fast-growing eucalyptus species exposed to field tests in three types of environments - outdoor, flooded site and forest canopy. We performed physical (mass loss, density and moisture content), colorimetric (CIEL*a*b* method) and visual (BS EN 252 standard) analyses in samples collected every 45 days for a total of 540 days.

\section{MATERIAL AND METHODS}

\section{Selection and preparation of material}

Twenty bangalay (Eucalyptus botryoides), lemon scented gum (Corymbia citriodora), grey ironbark (Eucalyptus paniculata) and forest red gum (Eucalyptus tereticornis) trees with approximately 60 years were selected from a homogeneous forest population located in Charqueadas, Rio Grande do Sul (29 $57^{\prime} 35^{\prime \prime}$ S51 $39^{\circ} 15^{\prime \prime}$ ). The selection of trees was based on the procedures of D5535-94 standard of American Society of Testing and Materials - ASTM 2010.

From each tree, the first log with 1,5 m length was cut and a central plank with $8 \mathrm{~cm}$ thickness was sawn. We prepared eight hundred and eighty-eight samples measuring $1 \mathrm{~cm} \times 1 \mathrm{~cm}$ x $20 \mathrm{~cm}$ from near to pith (juvenile wood) and near to bark (mature wood). All the samples were kept in a climatic chamber $\left(65 \%\right.$ relative humidity and $20^{\circ} \mathrm{C}$ temperature) to reach constant mass, which was the initial point for the characterization before the installation of the field test.

\section{Field tests}

We installed the field tests in Piratini, a municipality of Rio Grande do Sul State $\left(31^{\circ} 15^{\prime} 45^{\prime \prime} \mathrm{S}\right.$ $\left.53^{\circ} 07^{\prime} 36,5^{\prime \prime} \mathrm{O}\right)$. All the samples were organized in blocks in a vertical position with half of their length below the soil. The samples and the blocks were placed at $10 \mathrm{~cm}$ and $30 \mathrm{~cm}$ distances from each other, respectively (Figure 1). 


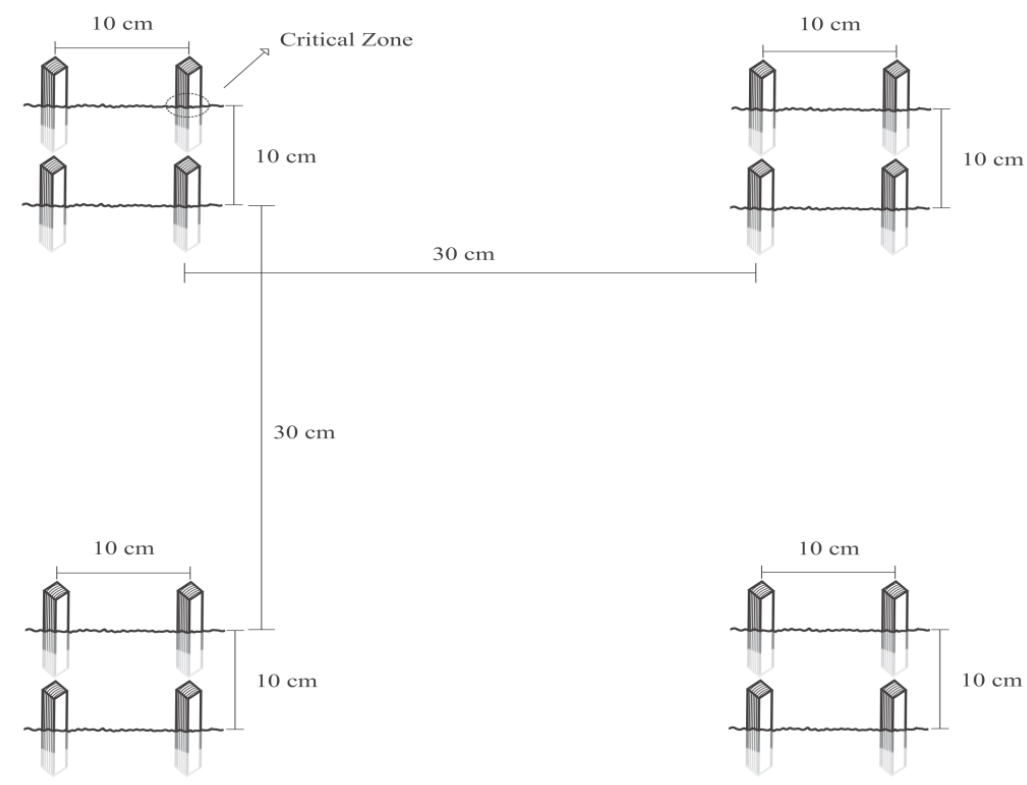

Figure 1. Schematic of the samples in the field tests.

Three sites with different microclimates were proposed - an outdoor site with low vegetation and full exposure to sunlight; a flooded site, in which the samples remained partially submerged $(\sim 2 \mathrm{~cm})$ in water; and inside a homogeneous forest population of Pinus elliottii (5 years old) with average height of $8 \mathrm{~m}$.

The samples were collected twelve times (every 45 days) in a total of 540 days of exposure. After each collection, the samples were kept in a climatic chamber $\left(65 \%\right.$ relative humidity and $20^{\circ} \mathrm{C}$ temperature) to reach constant mass for their characterization.

\section{Mass loss, density and equilibrium moisture content}

We determined the mass loss and the changes in the density of wood samples after the exposure to the field tests according to a procedure described by Mattos et al. 2014. Furthermore, the equilibrium moisture content was determined after drying the samples in an oven at $100 \pm 3^{\circ} \mathrm{C}$.

\section{Color changes}

Lightness $\left(L^{*}\right)$, green-red chromatic coordinate $\left(a^{*}\right)$, blue-yellow chromatic coordinate $\left(b^{*}\right)$, saturation $\left(C^{*}\right)$ and hue angle $(\mathrm{h})$ parameters were determined to investigate the color changes after exposure to the field tests. For that, we used a colorimeter CR-400 (Konica Minolta) configured with a D65 source light and angle of observation of $2^{\circ}$ according to CIE $L^{*} a^{*} b^{*}$ standard. We performed three measurements in the critical zone of the wood samples considering both radial and tangential sections. 1 .

Color difference $(\Delta \mathrm{E})$ of each sample exposed to the field tests were determined through equation

$$
\Delta E=\left(\Delta L^{* 2}+\Delta a^{* 2}+\Delta b^{* 2}\right)^{1 / 2}
$$


$\Delta L^{*}=$ lightness variation; $\Delta a^{*}=$ green-red chromatic coordinate variation; $\Delta b^{*=}$ blue-yellow chromatic coordinate variation; $\Delta E=$ color difference.

\section{Visual durability ratings}

We performed a visual evaluation of the wood samples as described in BS EN 252 standard from the European Committee for Standardization (CEN 1989). Phytosanitary conditions of each samples were determined considering their color and the presence of defects such as cracking, rot and mold. The criteria used were as follows: Grade $0=$ no attack; Grade $1=$ slight attack; Grade $2=$ moderate attack; Grade 3= severe attack; Grade 4= failure.

\section{RESULTS AND DISCUSSION}

\section{Summary of multi-factor ANOVA}

Multi-factor ANOVA (Table 1) proved that only mass loss $\left(\mathrm{M}_{1}\right)$ varied significantly for all the factors proposed in this study.

Table 1. Summary of multifactorial ANOVA as a function of the factors investigated.

\begin{tabular}{cccccc}
\hline & Specie & Type of wood & Type of field & $\begin{array}{c}\text { Time of } \\
\text { exposure }\end{array}$ & $\begin{array}{c}\text { Anatomical } \\
\text { direction }\end{array}$ \\
\hline $\mathrm{M}_{1}$ & $15,24^{*}$ & $11,95^{*}$ & $4,64^{*}$ & $16,87^{*}$ & - \\
$\rho$ & $6,56^{*}$ & $39,65^{*}$ & $0,08^{\mathrm{NS}}$ & $1,01^{\mathrm{NS}}$ & - \\
$\mathrm{M}_{c}$ & $18,07^{*}$ & $12,73^{*}$ & $0,76^{\mathrm{NS}}$ & $43,09^{*}$ & - \\
$\mathrm{L}^{*}$ & $31,59^{*}$ & $215,50^{*}$ & $158,44^{*}$ & $13,94^{*}$ & $2,60^{\mathrm{NS}}$ \\
$\mathrm{a}^{*}$ & $37,08^{*}$ & $6,73^{*}$ & $941,57^{*}$ & $76,21^{*}$ & $0,68^{\mathrm{NS}}$ \\
$\mathrm{b}^{*}$ & $13,45^{*}$ & $32,95^{*}$ & $904,34^{*}$ & $74,96^{*}$ & $0,19^{\mathrm{NS}}$ \\
\hline
\end{tabular}

Where: $\mathrm{M}_{1}=$ mass loss; $\rho=$ density; $\mathrm{M}_{\mathrm{c}}=$ moisture content; $L^{*=}$ lightness; $a^{*=}$ green-red chromatic coordinate; $b^{*}=$ blue-yellow chromatic coordinate; $*=$ significant at $5 \%$ of probability of error; ${ }^{\mathrm{NS}}=$ no significance.

No significance of type of field and exposure time in density, and no significance of type of field in moisture content indicate that these physical properties are not relevant to characterize the decay of the samples exposed to the field tests.

Regarding from the colorimetric parameters, changes to wood color are not dependent on the anatomical section when compared within the variables analyzed (Table 1). This corroborates with previous studies (Huang et al. 2012a, Huang et al. 2012b). Therefore, the anatomical direction variable can be rejected on a detailed analysis of changes to the color of decayed wood. Physical parameters were analyzed based on multi-factor ANOVA results, wherein three factors - Specie, Type of wood and Type of field - more influenced these parameters.

\section{Physical characterization}

The degree of mass loss increased as a function of exposure time. On the other hand, density and moisture content parameters decreased as a function of exposure time (Figure 2).

Mass loss greater than $10 \%$ for biodeteriorated samples exposed to a field test can result in significant damages to mechanical properties (Curling et al. 2002, Venalainen et al. 2014). This information indicates that the exposure time proposed in this study was suitable. 




Figure 2. Variation of mass loss, density and moisture content against exposure time to the field test.

In descending order, decay resistance of woods as a function of mass loss was: $E$. tereticornis, C. citriodora, E. paniculata e E. botryoides. This result is different from information reported by AS 5604 Australian Standard 2003, for the exposure conditions in Australia. Such discrepancy can be related to the levels of physiological activities of trees planted in Brazil and Australia, since both countries have distinct edaphoclimatic conditions (Marsden et al. 2013).

Therefore, Brazilian climate characteristics provide favorable conditions for the fast growth of eucalypts trees and, consequently, for a higher proportion of sapwood, which is less resistant than heartwood (Moya et al. 2014). The climatic conditions of exposure to the field test in this study is another aspect that should be considered, since the temperature and relative humidity of air influence significantly the physiological activity of fungi (Brischke et al. 2008).

Mature wood was more durable than juvenile wood. According to Latorraca et al. 2011, regardless of the variation in the constitution and the content of wood extractives of different species, mature wood is more durable due to the presence of phenolic compounds and flavonoids in the cell wall.

Concerning the exposure location, the flooded site provided the most favorable conditions to wood degradation, since the two other types of sites (outdoor and forest canopy) did not present considerable differences in relation to their degree of mass loss. We presume that result is due to the higher moisture content in the flooded site, which improves the physiological activity of xylophagous agents. According to Negrão et al. 2014, the ratio of wood deterioration exposed to xylophagous agents is related to the equilibrium moisture content of wood. 
The two most durable woods in this study (E. tereticornis e $C$. citriodora) presented the highest density values before the exposure to the field test $\left(0,992 \pm 0,008 \mathrm{~g}^{\mathrm{cm}} \mathrm{cm}^{-3}\right.$ e $0,975 \pm 0,008 \mathrm{~g}_{\mathrm{g}} \mathrm{cm}^{-3}$, respectively). On the other hand, the less durable woods showed the lowest density values $(0,869 \pm$ $0,008 \mathrm{~g} \cdot \mathrm{cm}^{-3}$ for E. botryoides and 0,916 $\pm 0,008 \mathrm{~g} \cdot \mathrm{cm}^{-3}$ for E. paniculata).

Nevertheless, in contrast with the behavior of density and moisture content, the degree of mass loss was different between E. tereticornis and C. citriodora, and between E. paniculata and E. botryoides. Therefore, we observed that the variation of density and moisture content indicates that these properties are not reliable alternatives to control the wood deterioration in a field test. However, in this study, the moisture content was determined in samples dried in a climatic chamber. Thus, the moisture content informed in this manuscript not represents the moisture levels of the samples during the field tests.

Brischke et al. (2014), reported that equilibrium moisture content is not an interesting parameter to predict wood deterioration because the effect of both temperature and wind superposes the effect of moisture content below the wood fiber saturation point ( $30 \%)$. According to Negrão et al. (2014), the type of xylophagous agent affects the wood's moisture retention, since some fungi attack the wood's polysaccharides and other fungi prefer the lignin as a nutrient.

\section{Color evaluation}

Regardless of species, type of wood or site of exposure factors, the average values of lightness $\left(L^{*}\right)$ and both chromatic coordinates $\left(a^{*}\right.$ and $\left.b^{*}\right)$ decrease as a function of exposure time to the field test (Figure 3).

All the colorimetric parameters decreased until 180 days of exposure, followed by a stabilization of the wood color (Figure 4).

From 45 days of exposure, treatment samples presented a considerable color difference to the unaided eye when compared to the control samples (Cui et al. 2004).

The color of natural wood can vary due to its extractives, such as fatty acids and steroids, an aspect that can be considered for heartwood and sapwood, and well as juvenile and mature wood (Prinisha 2011, Moya et al. 2012).

Outdoor exposure of wood results in initial color changes due to the oxidation of chromophore groups of lignin. This oxidation occurs because these chromophore groups absorb electromagnetic waves from solar radiation with wavelengths in the UV and visible region (George et al. 2005). Afterwards, drying gradients of wood are responsible for surface cracking that improve the susceptibility of attack by xylophagous agents (Evans et al. 2008). Thus, colonization of these fungi significantly influences the wood color (Hernandez 2012).

The color of mature wood was more stable than the color of juvenile wood. That possibly occurs due to the oxidation reactions and depolymerization of extractives in the formation of heartwood (Moya et al. 2012), since $\Delta \mathrm{E}$ of juvenile and mature wood was similar in the first 180 days of exposure, which indicate that both content and constitution of lignin are not related to this color difference.

Regarding the type of site, exposure to the flooded site resulted in less color changes than those verified in both forest canopy and outdoor sites. That behavior is not in accordance with the degree of mass loss and can be atributted to great presence of white-rot in the samples, although, in general, traces of soft-rot fungi, brown-rot fungi and white-rot fung are observed in the samples exposed in all types of fields. As observed for mass loss, color changes after exposure to field tests are significantly related to the type of fungi presented in the substrate. Therefore, correlations between mass loss and color parameters of wood in real conditions are subjective, sincethe same xylophagous agents are not always responsible for the variation of these characteristics. 


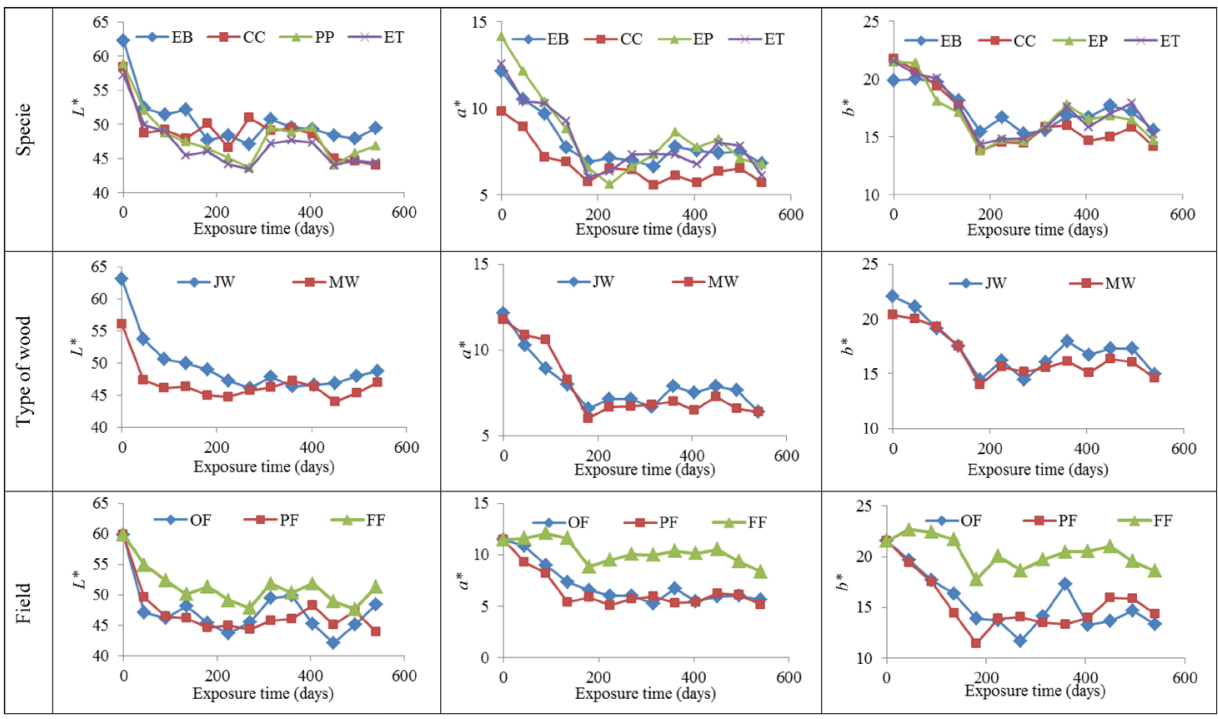

Figure 3. Average values of lightness $\left(L^{*}\right)$, green-red chromatic coordinate $\left(a^{*}\right)$ and yellow- blue chromatic coordinate $\left(b^{*}\right)$ against exposure time to the field test.

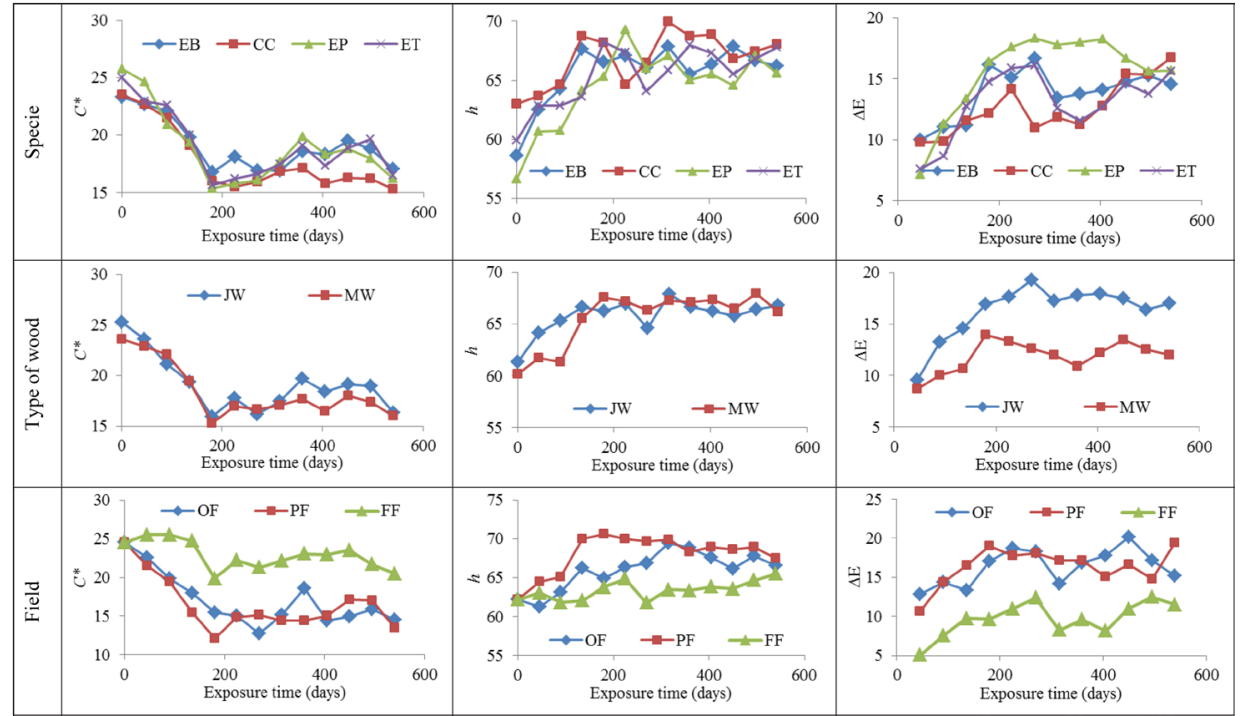

Figure 4. Average values of chromaticity $\left(C^{*}\right)$, hue angle $(\mathrm{h})$ e color difference $(\Delta \mathrm{E})$ against exposure time to the field test.Visual durability ratings

We performed a comparison between ratings of visual analysis and average values of all the technological properties characterized in this study. With the exception of density, all the properties presented synergetic results (Table 2). 
Table 2. Average values of physical properties as a function of visual durability ratings.

\begin{tabular}{ccccccc}
\hline Note & $\rho$ & $\mathrm{M}_{1}$ & $\mathrm{M}_{\mathrm{c}}$ & $L^{*}$ & $a^{*}$ & $b^{*}$ \\
\hline 0 & $0,881_{(0,15)} \mathrm{c}$ & $5,513_{(1,65)} \mathrm{a}$ & $11,712_{(0,50)} \mathrm{c}$ & $51,211_{(7,32)} \mathrm{c}$ & $10,350_{(2,54)} \mathrm{c}$ & $19,880_{(2,87)} \mathrm{d}$ \\
1 & $0,922_{(0,09)} \mathrm{d}$ & $5,803_{(2,30)} \mathrm{a}$ & $11,559_{(0,88)} \mathrm{c}$ & $48,746_{(0,52)} \mathrm{b}$ & $8,889_{(3,26)} \mathrm{b}$ & $18,325_{(4,07)} \mathrm{c}$ \\
2 & $\begin{array}{r}0,898_{(0,12)} \\
\mathrm{cd}\end{array}$ & $7,290_{(3,49)} \mathrm{b}$ & $11,194_{(0,92)} \mathrm{b}$ & $47,527_{(5,70)} \mathrm{a}$ & $7,068_{(2,77)} \mathrm{a}$ & $15,964_{(3,95)} \mathrm{b}$ \\
3 & $0,811_{(0,14)} \mathrm{b}$ & $14,031_{(9,09)} \mathrm{c}$ & $10,580_{(1,08)} \mathrm{a}$ & $46,884_{(5,79)} \mathrm{a}$ & $6,925_{(2,54)}^{\mathrm{a}}$ & $15,774_{(3,88)} \mathrm{b}$ \\
4 & $0,681_{(0,16)} \mathrm{a}$ & $29,975_{(21,33)} \mathrm{d}$ & $10,121_{(2,15)} \mathrm{a}$ & $42,888_{(7,19)} \mathrm{a}$ & $4,795_{(1,45)} \mathrm{a}$ & $11,743_{(1,87)} \mathrm{a}$ \\
\hline F-ratio & $28,55^{* *}$ & $118,75^{* *}$ & $45,13^{* *}$ & $21,19^{* *}$ & $78,36^{* *}$ & $63,27^{* *}$ \\
\hline
\end{tabular}

Average values followed by the same letter do not differ statistically according to the Tukey test at $1 \%$ of probability of error. $* *=$ significant at $1 \%$ of probability of error. Standard deviation in parentheses. Where: $\rho=$ density $\left(\mathrm{g} . \mathrm{cm}^{-3}\right) ; \mathrm{M}_{1}=$ mass loss (\%); $\mathrm{M}_{\mathrm{c}}=$ moisture content (\%); $\mathrm{L}^{*}=$ lightness; $a^{*}=$ green-red chromatic coordinate; $b^{*}=$ yellow-blue chromatic coordinate.

The absence of a relationship between density and visual analyzes can be attributed to the same evidence pointed out in the mass loss explanation. However, correlations between visual analyzes and density of wood in real conditions are subjective because not always the same xylophagous agent is responsible for the variation of these characteristics.

Mass loss of samples without attack (grade 0) and with slight attack (grade 1) did not differ statistically. From moderate attack (grade 2), the degree of mass loss improved significantly, and from severe attack (grade 3), the mass loss reached 10\%. These results are in accordance with other studies that affirm that significant damages to wood pieces occur when mass loss is equal or higher than $10 \%$ (Curling et al. 2002, Venalainen et al. 2014).

The relationship of visual analysis with $\mathrm{L}^{*}$ and $\mathrm{a}^{*}$ was similar. We observed a wood darkening and a decrease of red tones with increases to the degree of deterioration (until the moderate level of attack). From the moderate level of attack onwards, these colorimetric parameters did not differ significantly.

Yellow tones of all the samples exposed to the field tests decreased as a function of exposure time; however, the samples with moderate attack and severe attack did not show significant difference between them. We consider the absence of a relationship between $b^{*}$ and visual analysis as evidence of the inefficiency of that parameter to predict wood deterioration in the field tests.

The results for $\mathrm{L}^{*}$ and $\mathrm{a}^{*}$ parameters are in accordance with those found by Anti-Boasiako and Allotey 2010. These authors observed a significant connection between visual analysis and wood color. Furthermore, changes to wood color exposed to field tests occur due to the action of rain, which leaches some extractable wood compounds. On the other hand, Raberg et al. (2005), pointed out that the relationship between wood color and visual analysis is due to the presence of mould and stain fungi. 


\section{CONCLUSIONS}

E. tereticornis was the most resistant wood to decay. For the other species - in decreasing order of decay resistence: E. tereticornis, C. citriodora, E. paniculata and E. botryoides.

Mature wood was more resistant to decay than juvenile wood.

Among all the parameters evaluated in this study, mass loss was the best indicator for the wood decay resistance.

Regarding to the mass loss, the flooded site established better environmental conditions for the attack of xylophagous organisms than outdoor site and forest canopy.

Wood from all the species became dark and opaque on all field tests. Both yellowish and reddish pigments of these woods were lost during the exposure time.

Qualitative criteria of visual evaluation were able to predict satisfactorily the mass loss, the moisture content, the lightness and the green-red chromatic coordinate.

\section{REFERENCES}

American Society for Testing And Materials. ASTM. 2010. Practice for sampling forest trees for determination of clear wood properties. ASTM D 5535-94. In: Annual Book of ASTM Standards. Philadelphia.

Antwi-Boasiako, C.; Allotey, A. 2010. The effect of stake dimension on the field performance of two hardwoods with different durability classes. International Biodeterioration \& Biodegradation 64(4): 267-273.

Australian Standard. AS. 2003. Timber-natural Durability Ratings. In: Annual Book of AS Standards Australia. New South Wales.

Brischke, C.; Rapp, A.O.; Bayerbach, R.; Morsing, N.; Fynholm, P.; Welzbacher, C.R. 2008. Monitoring the "material climate" of wood to predict the potential for decay: Results from in situ measurements on buildings. Building and Environment 43 (10): 1575-1582.

Brischke, C.; Rolf-Kiel, H. 2010. Durability of European oak (Quercus spp.) in ground contact A case study on fence posts in service. European Journal of Wood Products 68(2): 129-137.

Brischke, C.; Meyer, L.; Olberding, S. 2014. Durability of wood exposed in ground e Comparative field trials with different soil substrates. International Biodeterioration \& Biodegradation 86(B): 108114.

Cui, W.; Kamdem, D.P.; Rysptra, T. 2004. Diffuse reflectance infrared Fourier transform spectroscopy (DRIFT) and color changes of artificial weathered wood. Wood and Fiber Science 46(3): 289-290.

CEN. 1989. European Committee for Standardization - CEN. BS EN 252. Field Test Method for Determining the Relative Protective Effectiveness of a Wood Preservative in Ground Contact. In: Annual Book of CEN Standards. Sydney.

Evans, P.; Urban, K.; Chowdhury, M. 2008. Surface checking of wood is increased by photodegradation caused by ultraviolet and visible light. Wood Science and Technology 42(3): 251-265.

Curling, S.F.; Clausen, C.A.; Winandy, J.E. 2002. Experimental method to quantify progressive stages of decay of wood by basidiomycete fungi. International Biodeterioration \& Biodegradation 49(1): 13-19. 
George, B.; Suttieb, E.; Merlin, A.; Deglise, X. 2005. Photodegradation and photostabilisation of wood - the state of the art. Polymer Degradation and Stability 8(2): 268-274.

Hernandez, V. 2012. Role of non-decay fungi on the weathering of wood. [Dissertation]. Concepción: University of Bio-Bio.

Huang, X.; Kocaefe, D.; Kocaefe, Y.; Boluk, Y.; Pichette, A. 2012a. Study of the degradation behavior of heat-treated jack pine (Pinus banksiana) under artificial sunlight irradiation. Polymer Degradation and Stability 97(7): 1197-1214.

Huang, X.; Kocaefe, D.; Kocaefe, Y.; Boluk, Y.; Pichette, A. 2012b. Spectrocolorimetric and chemical study on color modification of heat-treated wood during artificial weathering. Applied Surface Science 258(14): 5360-5369.

Latorraca, J.V.F.; Dünisch, O.; Koch, G. 2011. Chemical composition and natural durability of juvenile and mature heartwood of Robinia pseudoacacia L. Annals of the Brazilian Academy of Sciences 83(3): 1059-1068.

Little, N.S.; Schultz, T.P.; Diehl, S.V.; Nicholas, D.D.; Londo, A.J.; Musser, F.R.; Riggins, J.J. 2013. Field Evaluations of Subterranean Termite Preference for Sap-Stain Inoculated Wood. Journal of Insect Behavior 26(5): 649-659.

Magalhães, W.L.E.; Mattos, B.D.; Missio, A.L. 2012. Field testing of CCA-treated Brazilian spotted gum. International Biodeterioration \& Biodegradation 74(9): 124-128.

Marsden, C.; Nouvellon, Y.; Laclaub, J.; Corbeelse, M.; Mcmurtrief, R.E.; Stapeg, J.L.; Epronh, D.; Le Maireb, G. 2013. Modifying the G'DAY process-based model to simulate the spatial variability of Eucalyptus plantation growth on deep tropical soils. Forest Ecology and Management 301(1): 112-128.

Mattos, B.; Cademartori, P.H.G.; Lourençon, T.V.; Gatto, D.A.; Magalhães, W.L.E. 2014. Biodeterioration of wood from two fast-growing eucalypts exposed to field test. International Biodeterioration \& Biodegradation 93(8): 210-215.

Moya, R.; Bond, B.J.; Quesada, H. 2014. A review of heartwood properties of Tectona grandis trees from fast-growth plantations. Wood Science and Technology 48(2): 411-433.

Moya, R.; Fallas, R.S.; Bonilla, P.J.; Tenorio, C. 2012. Relationship between wood color parameters measured by the cielab system and extractive and phenol content in Acacia mangium and Vochysia guatemalensis from fast-growth plantations. Molecules 17: 3639-3652.

Negrão, D.R.; Silva-Júnior, T.A.F.; Passos, J.R.S.; Sansígolo, C.A.; Minhoni, M.T.A.; Furtado, E.L. 2014. Biodegradation of eucalyptus urograndis wood by fungi. International Biodeterioration \& Biodegradation 89(1): 95-102.

Prinisha, M. 2005. Characterisation and quantification of wood extractives and their impact on pitch. [Thesis]. Durban: University of KwaZulu-Natal.

Raberg, U.; Edlund, M.; Terziev, N.; Land, C.J. 2005. Testing and evaluation of natural durability of wood in above ground conditions in Europe - an overview. Journal of Wood Science 51(5): 429-440.

Thybring, E.E. 2013. The decay resistance of modified wood influenced by moisture exclusion and swelling reduction. International Biodeterioration \& Biodegradation 82(1): 87-95.

Venalainen, M.; Partanen, H.; Harju, A. 2014. The strength loss of Scots pine timber in an accelerated soil contact test. International Biodeterioration \& Biodegradation 86(B): 150-152.

Venmalar, D.; Nagaveni, H.C.; Remadevi, O.K.; Babu, P.; Vijayalakshmi, G.; Shalini, P. 2011. Resistance of different age groups of timber of Ailanthus species to biodeterioration in Karnataka conditions. Journal of the Indian Academy of Wood Science 8(2): 165-168. 